\title{
カッオの生化学的研究一 $\mathrm{V}$. 幽門垂に於ける燐の分布
}

\author{
堀口吉重・柏田研一 \\ （鹿児島大学水産学部） \\ Biochemical Studies on Skipjack (Katsuwonus vagans)-V \\ Distribution of Phosphorous in Pyloric Coeca \\ Yoshishige HoriguchI and Ken'ichi KaSHIWADA
}

The authors studied the distribution of phoshorous in pyloric coeca of skipjack, and obtained the following results.

1) The total phosphorous content was about $130 \mathrm{mg} \%$, inorganic phosphorous $48 \mathrm{mg} \%$ and organic phosphorous $82 \mathrm{mg} \%$-lipoid phosphorous $5 \mathrm{mg} \%$, nucleic-acid phosphorous $37 \mathrm{mg} \%$ and phosphoprotein phosphorous $2 \mathrm{mg} \%$, respectively, in the organic phosphorous.

2) The amount of lipoid phosphorous did not change by storing, but nucleic-acid and phosphoprotein phosphorous decreased rapidly with the lapse of time.

3) Pyloric coeca contained much more organic phosphorous and less lipoid phosphorous as compaired with the muscle of skipjack.

緒暳

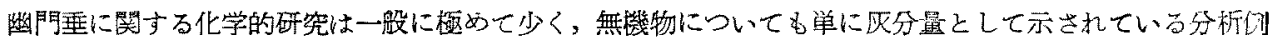

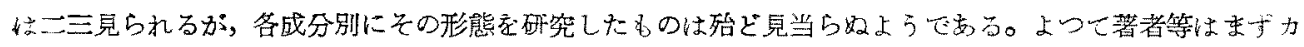

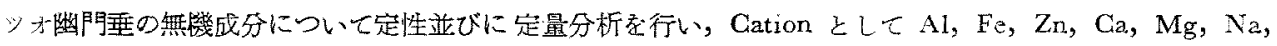

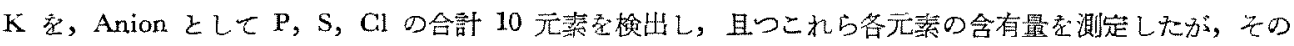
結果性本研究の第 2 冁》として本誌に発表した。これら元素の中，憐は動物体に然ける多くの重要な生理作

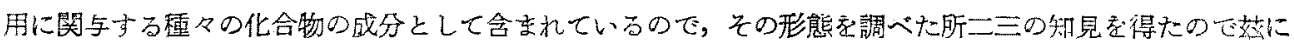
粮告する。

カッオのよろな外洋性魚類では一般にその生活時に於ける成分の実態を知ることはかなり困難るする。柘

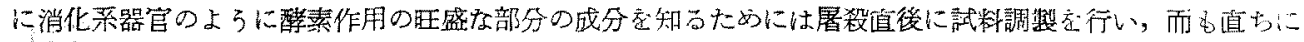

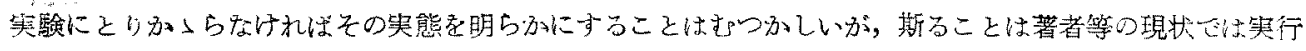

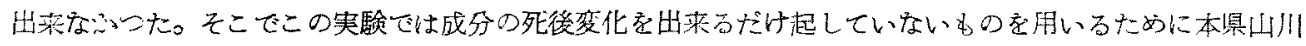

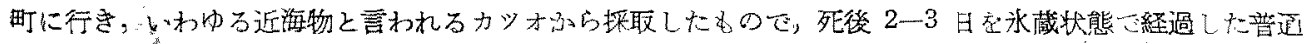

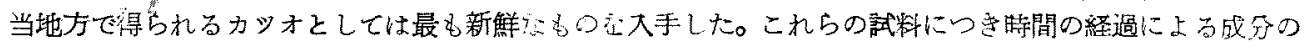

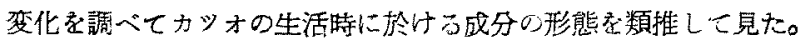

実験

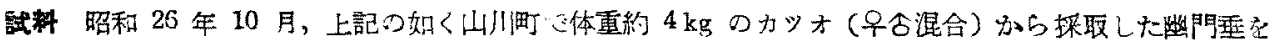

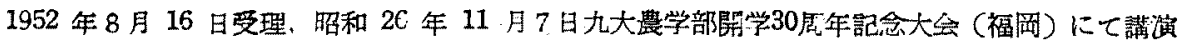




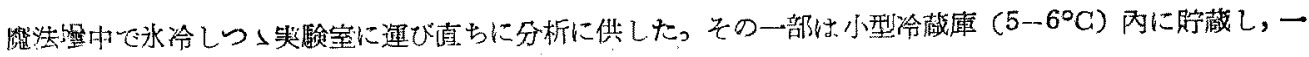

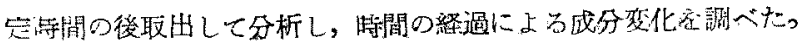

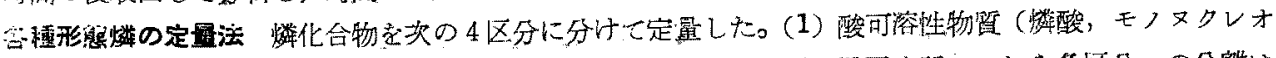

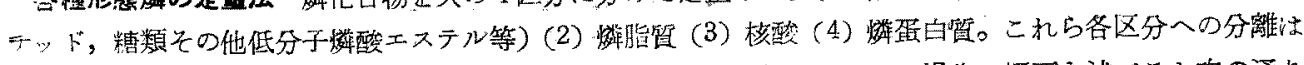

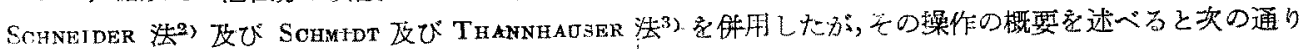
でるる。

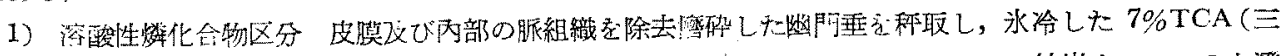

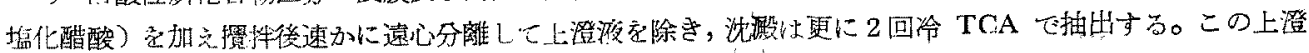

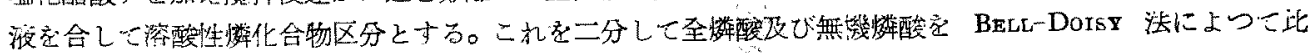

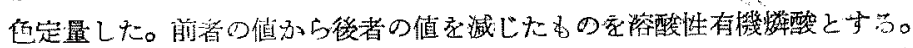

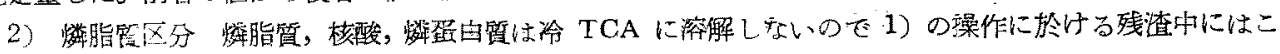

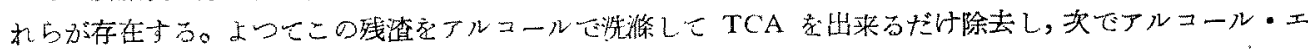

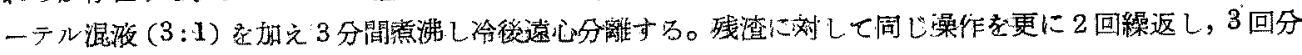

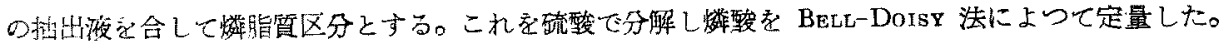

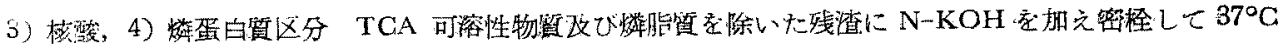
に15 㭙間放置すると骨以外の組織は殆ど溶解寸るが, この場合 DNA (Desoxypentosenucleic acid)，PNA

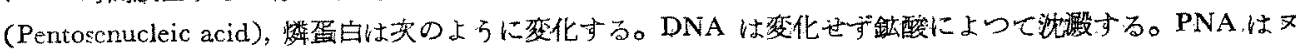

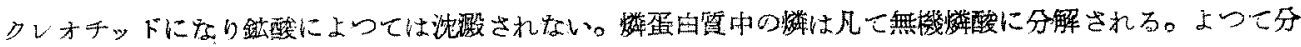

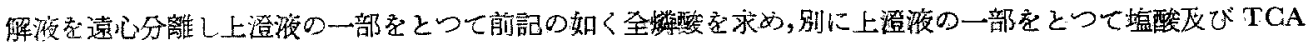

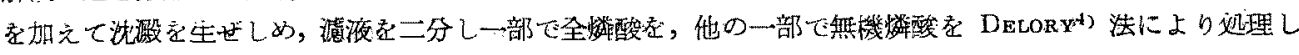

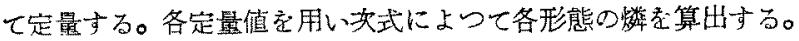

(アルカリ処理の全燐酸)一(酸性媳液の全燐酸) $=\mathrm{DNA}$ の敞

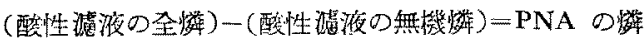

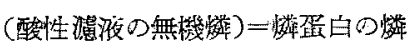

\section{成綪並に考察}

以上の方法によつて行つた舆験成績は次表の通りである。

Table 1. Distribution of phosphor in pyloric coeca of skipjack. (mg. per $1 \mathrm{cog}$. of fresh matter)

\begin{tabular}{c|c|c|c}
\hline Days of storage (at 5-6 $6^{\circ} \mathrm{C}$. ) & 0 & 7 & 11 \\
\hline Total P & 129 & 129 & 129 \\
Acid soluble total P & 85 & 111 & 124 \\
" inorganic P & 48 & 100 & 122 \\
$\prime \quad$ organic P & 37 & 11 & 2 \\
Phospholipid P & 5.4 & 5.1 & 5.0 \\
DNA-P & 17 & 2 & 0 \\
PNA-P & 20 & + & 0 \\
Phosphoprotein P & 2 & 0 & 0 \\
\hline
\end{tabular}

本笑験に供した幽門垂の 全燐は鮮組織内 $129 \mathrm{mg} \%$ であつた。その大部分は前 記の区分に彷之ば TCA 溶 性で，最初 $85 \mathrm{mg} \%$ (全楛 の 66\%弱) であるが、これ はその後次第に增加！11日 後に於ては 全燐の約 $96 \%$

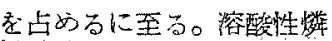
の中では最初は無機性燐の 万が有機性燐上りる少しい

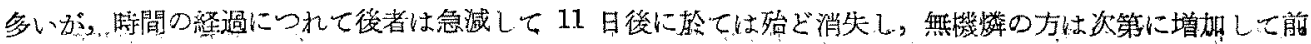

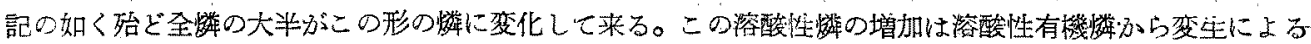

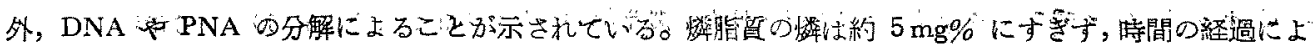




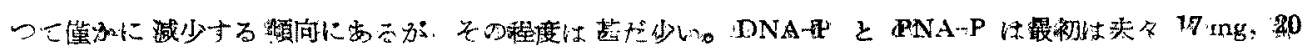

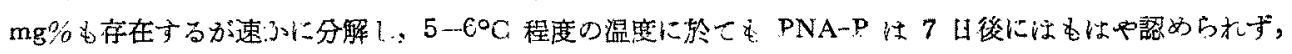

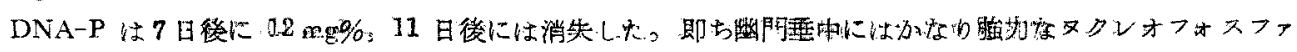

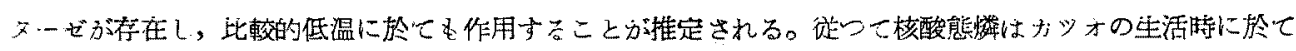

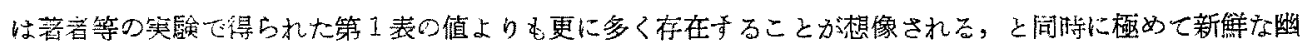

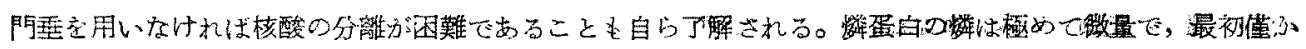

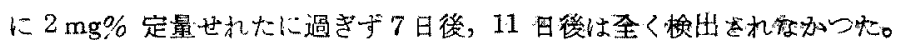

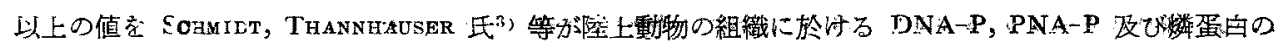

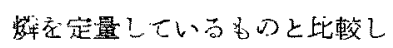
こ見ると第 2 表の通りで，カッ 才幽诃重に於ける含監は概して 遥かに少いことが解っ。

并し前記の如く幽阿垂に㓋て はこの形の矮は分解され易いの で，渚者等の得た值から犆らに ホッオ幽門垂に於ける核酸の量 惊陸上動物の諸器官に於けるよ りる遥加少いるのであると断 定することは出来ない。

觔肉に含まれる橉の形態につ Table 2. Desoxypentosenucleic acid (DNA)- and ribonucleic a.cid (RNA) phosphorous content in fresh tissue. (mg.\%)

\begin{tabular}{|c|c|c|c|}
\hline Tissue & DNA & $\mathrm{RNA}$ & Phosphoprotein \\
\hline Thymus (Calf) & 145 & 37 & \pm \\
\hline$" 1$ & 182 & 56 & " \\
\hline Pencreas (Cettle) & 6.5 & 100 & \% \\
\hline Liver (Rat) & 26.0 & 87.3 & $" \prime$ \\
\hline$" \prime$ & 22.5 & 102 & $" \prime$ \\
\hline Spleen $(" \prime)$ & 54.5 & 70.0 & $\prime \prime$ \\
\hline Brain (" ) & 51.1 & 32.6 & $" \prime$ \\
\hline Kidney $(")$ & 33.5 & 47.0 & $" r$ \\
\hline Pyloric cceca (Skipjack) & 17 & 20 & 2 \\
\hline
\end{tabular}

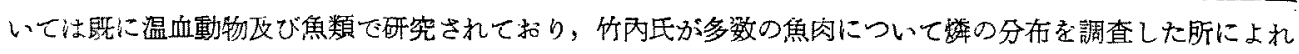

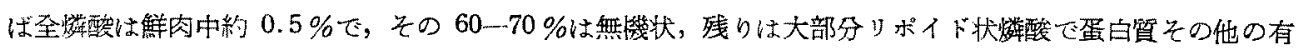

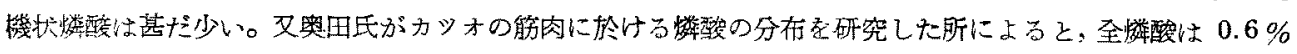
強でそのりポイド状燐酸は普通肉に於ては全燐酸の約 $30 \%$ ，血台肉では約 $40 \%$ に相当しているが，これ

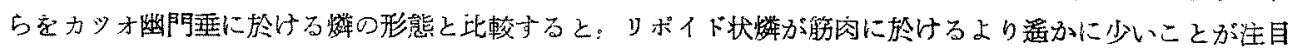
せられる。

燐々動物体に於ては $\mathrm{Ca}$ 及び $\mathrm{Mg}$ と化合して骨の主体をなすが，更に核蛋白質の構成分子となつて細胞

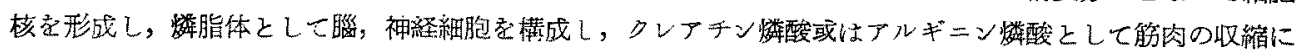
関与し，又体液中に存在し二酸，坥基の平衡に重要な作用を行い，又核酸が蛋白合成に必要であるとの仮説

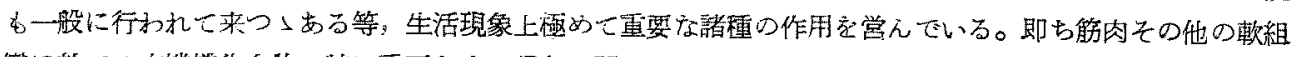

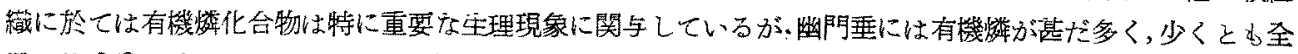

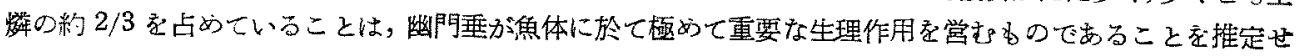
さめるに足るるのと思う。

\section{摘要}

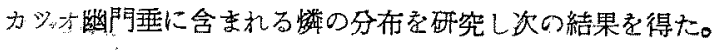

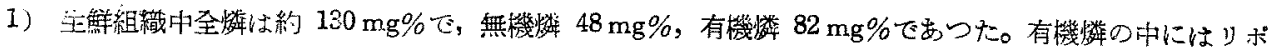

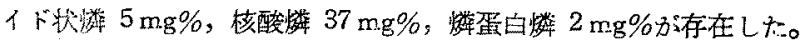

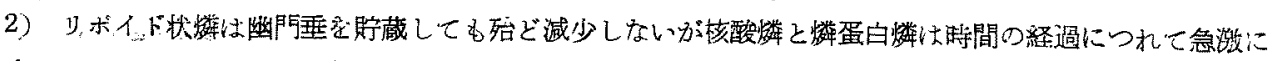
減少するのでカカッの生活体に於ては此等の有機潾は更に多量存在することが想像される。

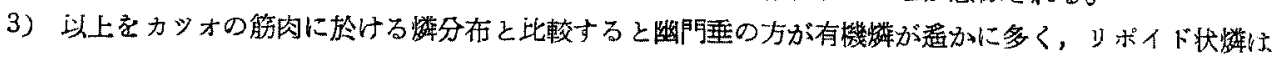




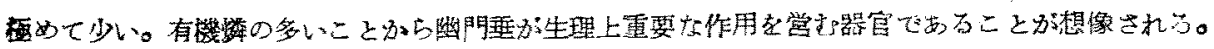

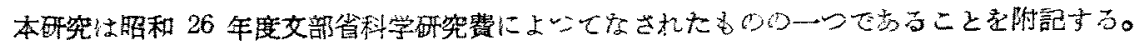

女塥

1）堀口，松田，植本：日水誌，18. 279 (1952)

2) W. C. Schmeider: J. Biol. Chem, 161, 293 (1945).

3) Sohm ddt and Thanngauser: J, Bio!. Chem, 161, 83 (1945).

4) DELoRY: Biochem. J., 32, 1161 (1938). 